\title{
A COMPARATIVE CONSTITUTIONAL ANALYSIS OF THE RIGHT TO LIFE IN AFRICA
}

\author{
by Petronell Kruger* \& Nomfundo Ramalakana**
}

\section{Introduction}

This article provides a brief study of the constitutional protection of the right to life in Africa. This entails looking at the provisions on the right to life contained in various constitutions of African States, as well as jurisprudence on the matter of the right to life, and a comparison with the relevant international standards (United Nations and African Union). This article is based on a clinical group led by Prof Christof Heyns, the United Nations (UN) Special Rapporteur on extrajudicial, summary or arbitrary executions. The focus of the clinical group was issues surrounding the right to life as envisaged in his mandate.

As a point of departure, we will discuss the relevant international instruments enshrining the right to life, as well as looking at African jurisprudence on the issue of the right to life. This will be followed by a textual categorisation of the different constitutional provisions relating to the right to life in the $54 \mathrm{UN}$ member States in Africa. We will compare the different formulations of the right to life, attempt to identify patterns of States with a similar colonial heritage and then attempt to source the reasons for such emerging patterns. After this investigation and comparison we will attempt to draw a corollary link between a clear enunciation of the right to life in constitutions and low levels of violence. Based on our findings, we will propose some recommendations.

This article will not consider the constitutions of any country that is not a member of the United Nations. Hence, entities such as Somaliland and the Sahrawi Arab Democratic Republic will not be considered. Only the constitutional provisions directly linked to the protection of the right to life will be examined. The relevant Egyptian, Libyan and Tunisian constitutional provisions will be briefly looked at, but excluded for purposes of analysis. ${ }^{1}$

* $\quad$ Fourth year LLB, Tutor Department of Private Law, University of Pretoria.

** Fourth year LLB, Tutor Department of Private Law, University of Pretoria. See 5.4. below for a discussion on the reasons for the exclusion. 


\section{Brief overview of the international standard}

The right to life is protected in a number of human rights instruments. Article 3 of the Universal Declaration of Human Rights provides that everyone has the right to life, liberty and security of the person. ${ }^{2}$ Article 6 of the International Covenant on Civil and Political Rights (ICCPR) provides that everyone has an inherent right to life which is to be protected by law and that no one may be arbitrarily deprived of his life. ${ }^{3}$ Furthermore, Article 4 of the African Charter on Human and Peoples' Rights provides that human beings are inviolable and that every human being shall be entitled to respect for his life and the integrity of his person and no one may be arbitrarily deprived of this right. ${ }^{4}$

The right to life is a fundamental right as no other right can be exercised and enjoyed without it. It has thus been referred to as a meta-right. ${ }^{5}$ Article 4 of the ICCPR clearly states, that no derogation from the right to life is permissible, not even during a state of emergency. The use of the words inherent in Article 6 of the ICCPR and 'inviolable' in Article 4 of the ACHPR stresses the importance of this right. In General Comment No 6, the Human Rights Committee states that 'inherent right to life' should not be understood in a restrictive manner and that the protection of the right to life entails both a negative obligation not to take someone's life and a positive obligation to protect the right to life, except in certain exceptional cases. $^{6}$

The African Commission recognises the uniqueness of human rights in Africa and has interpreted the right to life to provide the widest possible protection to persons. In the Social and Economic Rights Action Centre (SERAC) and Another $v$ Nigeria, it recognised the right to life of the Ogoni Community as a whole and held that continuous pollution, killings and the widespread terrorisation of the Ogoni people was a violation of their way of life. ${ }^{7}$ Furthermore, the African Commission recognise the right to life, beyond the scope of merely prohibiting the arbitrary deprivation thereof by the state and its organs. In the Malawi African Association and Others v Mauritania communication, the complainant was still alive but in hiding for fear

Universal Declaration of Human Rights GA res 217A (III), UN Doc A/810 at 71 (1948).

International Covenant on Civil and Political Rights GA res 2200A (XXI), 21 UN GAOR Supp (No 16) at 52, UN Doc A/6316 (1966), 999 UNTS 171.

4 African Charter on Human and Political Rights OAU Doc CAB/LEG/67/3 rev 5, 21 ILM 58 (1982).

5 Report of the Special Rapporteur on extrajudicial, summary or arbitrary executions, Christof Heyns, Death Penalty, A/67/275.

6 General Comment No 06: The right to life (art 6):1982/04/30.

7 Social and Economic Rights Action Centre (SERAC) and Another v Nigeria (2001) AHRLR 60 (ACHPR 2001), 67-68. 
of his life. The African Commission held that it would be 'a narrow interpretation of this right - the right to life - to think that it can only be violated when one is deprived of it' and the right to respect for one's life and the dignity is protected even when the violation is due to inducing a person to live in a 'state of constant fear and/or threats' ${ }^{8}$ In the words of the African Commission in the African Commission Forum of Conscience $v$ Sierra Leone, the right to life is the 'fulcrum of all other rights, it is the fountain through which other rights flow.' 9

The right to life is threatened both vertically and horizontally. In the vertical relationship between the state and its legal subjects, the right to life is threatened particularly by arbitrary deprivation of the right by the state and its agents. The right to life is also threatened in the horizontal relationships between people. As already mentioned, this paper will specifically be focusing on the right to life from the vertical perspective, dealing with arbitrary or summary executions, the death penalty and the use of force by police and law enforcement agencies.

General comment No. 6 provides that the right to life should not be interpreted narrowly. It further states that there is a 'supreme duty' on states to prevent wars, acts of genocide and other acts of mass violence which causes the arbitrary loss of life, prevent the arbitrary deprivation of life and in relation to the death penalty. It states that although there is no obligation to abolish the death penalty, there is an obligation to limit its use and, in particular, to abolish it for other than the 'most serious crimes'.10

The right to life as it is guaranteed, entails that at the very least, states should refrain from the arbitrary and targeted killings of individuals under their jurisdiction. However, the right to life, although supreme, is not absolute and can be limited by laws that provide for the death penalty as well as those that govern the rules relating to private defence, either by law enforcement officials or individuals.

\section{General overview of the right to life in African Constitutions}

As base to all subsequent rights, it is difficult to imagine that the right to life could be formulated in divergent ways. However, it is clear after a brief examination of the textual framing of the right to life in 2000), para 120

African Commission Forum of Conscience v Sierra Leone (2000) AHRLR 293 (ACHPR 2000) para 19.

10 General Comment No 06: The right to life (art 6): 1982/04/30. 
the 54 constitutions of African states that no true uniformity is present. This paper will divide the different manifestations into one of three categories; the right to life as protected in the absence of any internal limitation clauses, the right to life protected subject to internal limitations and an inferential protection of the right to life. In addition, the differences in the protection of the right to life in the revolutionary documents of the Arab-Spring countries, i.e. Tunisia, Egypt and Libya and the predecessors to such documents will be briefly explored.

\subsection{The right to life protected in the absence of internal limitations}

Cape Verde incorporates a two-step approach by first stating that '[h] uman life and the physical and spiritual integrity of the people shall be inviolable' and that 'in no case shall there be the death penalty.'11 Guinea-Bissau, Mozambique, Namibia and São Tomé and Principe also follow this model. ${ }^{12}$ Cote D'lvoire expands on this structure a little by prefacing the text that gives expression to the right of life by reiterating that the 'individual is sacred', 'born free and equal before the law' and that the right is inalienable. ${ }^{13}$ The same provision then holds that '[p]ublic authorities have the obligation to respect, protect and promote the individual' Any sanction leading to the deprivation of human life is forbidden.'14

Other States opt for a very simple provision, mentioning nothing substantive other than acknowledging or guaranteeing the right to life. Angola, Burundi, South Africa, Tanzania and Rwanda fall into this sub-category. The Rwandan Constitution states in article 20 that '[e]very person has the right to life. No person shall be arbitrarily deprived of life.' 15 The Angolan text provides that '[t]he state shall respect and protect human life, which is inviolable., 16 The South African Constitution concisely states that '[e]verybody has the right to life' without expanding on the concept further. ${ }^{17}$ Tanzania's constitution provides that every person has the 'right to live and to the protection of his life by the society in accordance with law' - a relatively simple formulation also. ${ }^{18}$ Burundi's Constitution simply

The Constitution of the Republic of Cape Verde 1999 secs 27(1) \& (2)

The Constitution of the Republic of Mozambique 2004 secs 40(1) \& (2); The Constitution of the Republic of Namibia $1990 \mathrm{sec} 6$; The Constitution of the Democratic Republic of São Tomé and Principe $1990 \mathrm{sec} 21(1)$; The Constitution of the Republic of Guinea-Bissau $1996 \mathrm{sec} 36$ \& 38.

3 The Constitution of the Republic of Cote D'Ivoire $2000 \mathrm{sec} 2$.

Section 2 .

The Constitution of the Republic of Rwandan $2003 \mathrm{sec} 20$.

The Constitution of the Republic of Angola $2010 \mathrm{sec} 30$.

The Constitution of the Republic of South Africa $1996 \mathrm{sec} 11$. The Constitution of the Republic of Tanzania $1977 \mathrm{sec} 14$. 
states that '[e]very woman, every man has the right to life." ${ }^{19}$ The Algerian Constitution doesn't use the word 'life', but does provide in article 34 that the 'State guarantees the inviolability of the human entity. ${ }^{20}$ This is deemed an unqualified right to life provision. ${ }^{21}$ The Constitution of Morocco describes the right to life as 'the first right for every human being. 22 The Provisional Constitution of Somalia enshrines the right to life in article $13 .{ }^{23}$

Finally, there are some states that group the right to life with other rights under the same provision. These are states such as Benin and Mali (other rights: security, integrity and liberty), Congo (right to free development and the full flowering of personality), Democratic Republic of Congo (physical integrity and development of personality), South Sudan and Sudan (dignity and integrity), Togo (integrity and safety), Chad (personal integrity, security, private life and property) and Burkino Faso which lists the right to life along with the prohibition on forms of the 'deprecation of man' such as slavery, torture, cruel and degrading treatment and the mistreatment of children. ${ }^{24}$ Djibouti has a large grouping of rights. Article 10 of its Constitution protects the right to life, liberty, security and various rights to give effect to a fair trial in one provision. ${ }^{25}$ The Senegalese Constitution groups the rights it refers to as 'sacred and inalienable' which forms the basis of 'human community' and of 'peace and community'. ${ }^{26}$ Guinea also lists a large array of protections in one provision. ${ }^{27}$

\subsection{The right to life protected subject to internal limitations}

There seem to be four general formulations which include an internal limitation; listing the exception of the death penalty, listing the exception of the death penalty plus the circumstances under which the death penalty can be imposed, listing the death penalty plus other circumstances to limit the right to life and instances where there is

The Post-Transition Interim Constitution of the Republic of Burundi $2005 \mathrm{sec} 24$.

The Constitution of Algeria $1996 \mathrm{sec} 34$.

LM Chenwi Towards the abolition of the death penalty in Africa: A human rights perspective (2007) 75.

The Constitution of the Republic of Morocco $2012 \mathrm{sec} 20$.

The Provisional Constitution of the Federal Republic of Somalia 2012; The Somalian Constitution is in the process of being redrafted, but this report will not rely on such document as it is still subject to intense commentary and the likelihood of content-change is high.

24 The Constitution of the Republic of Benin $1990 \mathrm{sec}$ 15; The Constitution of Burkino Faso $2000 \mathrm{sec} 2$; The Constitution of the Republic of the Congo $2006 \mathrm{sec}$ 7; The Constitution of the Republic of Mali $1992 \mathrm{sec}$ 1; The Constitution of the Republic of South Sudan $2011 \mathrm{sec} 11$; Constitution of the Republic of Togo $1992 \mathrm{sec} 13$; Constitution of Chad 1996 sec 17; Democratic Republic of Congo $2001 \mathrm{sec}$ 16; The Interim National Constitution of the Republic of Sudan $2005 \mathrm{sec} 28$.

The Constitution of the Republic of Djibouti sec 1992.

The Constitution of the Republic of Senegal $2001 \mathrm{sec} 7$.

The Constitution of Guinea 1990 sec 6 . 
no mention of the death penalty but other limitations are included. To aid in summarising the different formulations, the following table is employed:

\begin{tabular}{|c|c|c|c|c|c|c|}
\hline & $\begin{array}{l}\text { Death } \\
\text { penalty } \\
\text { alone }\end{array}$ & $\begin{array}{l}\text { Death penalty } \\
\text { plus the } \\
\text { circumstances }\end{array}$ & $\begin{array}{l}\text { Legitimate } \\
\text { use of } \\
\text { force by } \\
\text { police or } \\
\text { military }\end{array}$ & \begin{tabular}{|l|} 
Self- \\
defense \\
or \\
private \\
defense
\end{tabular} & $\begin{array}{l}\text { Lawful } \\
\text { act of } \\
\text { war }\end{array}$ & Abortion \\
\hline Botswana $^{a}$ & $Y$ & $\mathrm{~N}$ & $\mathrm{Y}$ & $Y$ & $Y$ & $\mathrm{~N}$ \\
\hline $\begin{array}{l}\text { Equitorial } \\
\text { Guinea }^{b}\end{array}$ & $\mathrm{Y}$ & $\mathrm{N}$ & $\mathrm{N}$ & $\mathrm{N}$ & $\mathrm{N}$ & $\mathrm{N}$ \\
\hline Ethiopia $^{\mathrm{C}}$ & $\mathrm{Y}$ & $\mathrm{N}$ & $\mathrm{N}$ & $\mathrm{N}$ & $\mathrm{N}$ & $\mathrm{N}$ \\
\hline Eritrea $^{\mathrm{d}}$ & $\mathrm{Y}$ & $\mathrm{N}$ & $\mathrm{N}$ & $\mathrm{N}$ & $\mathrm{N}$ & $\mathrm{N}$ \\
\hline $\begin{array}{l}\text { The } \\
\text { Gambiae }\end{array}$ & $\mathrm{N}$ & $\mathrm{Y}$ & $\mathrm{Y}$ & $\mathrm{Y}$ & $\mathrm{Y}$ & $\mathrm{N}$ \\
\hline Ghana $^{f}$ & $Y$ & $\mathrm{~N}$ & $\mathrm{Y}$ & $\mathrm{Y}$ & $\mathrm{Y}$ & $\mathrm{N}$ \\
\hline Kenyag & $\mathrm{N}$ & $\mathrm{N}$ & $\mathrm{N}$ & $\mathrm{N}$ & $\mathrm{N}$ & $\mathrm{Y}$ \\
\hline Lesotho $^{\text {h }}$ & $\mathrm{Y}$ & $\mathrm{N}$ & $\mathrm{Y}$ & $\mathrm{Y}$ & $\mathrm{Y}$ & $\mathrm{N}$ \\
\hline Liberia $^{1}$ & $\mathrm{Y}$ & $\mathrm{N}$ & $\mathrm{N}$ & $\mathrm{N}$ & $\mathrm{N}$ & $\mathrm{N}$ \\
\hline Malawi $^{\top}$ & $\mathrm{Y}$ & $\mathrm{N}$ & $\mathrm{N}$ & $\mathrm{N}$ & $\mathrm{N}$ & $\mathrm{N}$ \\
\hline Mauritius $^{\mathrm{k}}$ & $\mathrm{Y}$ & $\mathrm{N}$ & $\mathrm{Y}$ & $\mathrm{Y}$ & $\mathrm{Y}$ & $\mathrm{N}$ \\
\hline Nigeria' $^{\top}$ & $\mathrm{Y}$ & $\mathrm{N}$ & $\mathrm{Y}$ & $\mathrm{Y}$ & $\mathrm{N}$ & $\mathrm{N}$ \\
\hline Seychelles $^{\mathrm{m}}$ & $\mathrm{N}$ & $\mathrm{N}$ & $\mathrm{N}$ & $\mathrm{N}$ & $\mathrm{Y}$ & $\mathrm{N}$ \\
\hline $\begin{array}{l}\text { Sierra } \\
\text { Leone }^{\text {n }}\end{array}$ & $\mathrm{Y}$ & $\mathrm{N}$ & $\mathrm{Y}$ & $\mathrm{Y}$ & $\mathrm{Y}$ & $\mathrm{N}$ \\
\hline Swaziland $^{\circ}$ & $\mathrm{Y}$ & $\mathrm{N}$ & $\mathrm{Y}$ & $Y$ & $\mathrm{~N}$ & $\mathrm{Y}$ \\
\hline Uganda $^{\mathrm{P}}$ & $\mathrm{Y}$ & $\mathrm{N}$ & $\mathrm{N}$ & $\mathrm{N}$ & $\mathrm{N}$ & $\mathrm{Y}$ \\
\hline Zambiaq & $\mathrm{Y}$ & $\mathrm{N}$ & $\mathrm{Y}$ & $\mathrm{Y}$ & $\mathrm{Y}$ & $\mathrm{Y}$ \\
\hline Zimbabwe $^{r}$ & $\mathrm{~N}$ & $Y$ & $\mathrm{~N}$ & $\mathrm{~N}$ & $\mathrm{~N}$ & $\mathrm{Y}$ \\
\hline
\end{tabular}

The Constitution of Botswana $1966 \mathrm{sec} 4$.

The Constitution of the Republic of Equatorial Guinea $1999 \mathrm{sec} 13$.

The Constitution of Ethiopia $1995 \mathrm{sec} 15$.

The Constitution of Eritrea $1997 \mathrm{sec} 15$.

The Constitution of the Republic of the Gambia $2001 \mathrm{sec} 18(1)$.

The Constitution of the Republic of Ghana $1996 \mathrm{sec} 13(1)$.

The Constitution of Kenya 2010 sec 26.

The Constitution of Lesotho $2001 \mathrm{sec} 5$.

The Constitution of the Republic of Liberia $1984 \mathrm{sec} 20$.

The Constitution of the Republic of Malawi 2001 sec16.

The Constitution of the Republic of Mauritius $2001 \mathrm{sec} 4(1)$.

The Constitution of the Federal Republic of Nigeria $1999 \mathrm{sec} 33(1)$

The Constitution of the Republic of Seychelles $1993 \mathrm{sec} 15$.

The Constitution of Sierra Leone $1996 \mathrm{sec}$ 16(1).

The Constitution of the Kingdom of Swaziland $2005 \mathrm{sec} 15$

The Constitution of the Republic of Uganda $1995 \mathrm{sec} 22$.

The Constitution of the Republic of Zambia $1996 \mathrm{sec} 12$.

The Constitution of the Republic Zimbabwe 2013 of sec 48.

$(\mathrm{Y}=$ yes; $\mathrm{N}=\mathrm{no})$ 
A last additional category is also present. This is where the state's constitution makes a vague reference to an internal limitation such as is illustrated by article 3 of the Central African Republic's Constitution that holds while '[e]veryone has the right to life and bodily integrity' such rights 'may only be affected by the application of law.'28 Niger's constitution protects the right to life, amongst other rights, according to 'the conditions established by law. 29

\subsection{Inferential protection of the right to life}

Some states don't have a clear protection of the right to life in their constitutions but such a right can be inferred through mechanisms such as the incorporation of international instruments. Cameroon is an apt example. The preamble alone provides for the protection of fundamental rights as can be found in the Universal Declaration of the Rights of Man. ${ }^{30}$ The Comoros follow a similar approach. ${ }^{31}$ The Constitution of the Gabonese Republic actually mentions certain fundamental human rights within the body of the text, ${ }^{32}$ but fails to make express mention of the right to life. The right to life can nevertheless, be incorporated through a reference in the preamble to the Universal Declaration of Human and People's Rights and the African Charter.

\subsection{Arab-Spring countries}

The Violet Revolution of 2011 in Tunisia started the so-called Arab Spring which led to mass civilian uprising and regime changes in a number of Arab-speaking countries. This impacted on the legitimacy of at least three African countries' constitutions - Tunisia, Egypt and Libya. The separation of a discussion on the right to life in these states is due to the irrelevance of the states' old constitutions and the paradigm shift within these countries concerning the role and rights of the populations.

Tunisia started drafting a new constitution in 2012. The Tunisian constitution provides that " $[\mathrm{t}]$ he right to life is sacred and cannot be prejudiced except in exceptional cases regulated by law. ${ }^{, 33}$ In Libya, an official constitutional declaration was made in 2011 which reads: 'Human rights and his basic freedoms shall be respected by the State. The state shall commit itself to join the international and regional declarations and charters which protect such rights and freedoms. 34

\footnotetext{
The Constitution of the Central African Republic 2004.

The Constitution of the Seventh Republic of Niger $2010 \mathrm{sec} 12$

The Constitution of the Republic of Cameroon 1996 preamble.

The Constitution of the Comores 1996 preamble.

Constitution of the Gabonese Republic $1991 \mathrm{sec} 1$.

Draft Constitution of the Republic of Tunisia $2014 \mathrm{sec} 22$.

The Libyan Constitutional Declaration 2012 sec 11.
} 
This stands in contrast with the 1977 Constitution, which contained no right to life provision. ${ }^{35}$ The Egyptian Constitution of 1980 did not contain a provision protecting the right to life and the new 2014 constitution also has no express provision. ${ }^{36}$ Due to the unique circumstances prevailing in these countries, we will exclude them from further analysis or discussion in this paper to try and normalise our data findings.

\section{Patterns, comments and conclusions}

\subsection{Correlation between categories and previous colonial powers}

As a brief point of interest, the three different categories of formulations as identified in 4.1 to 4.3 will be sub-divided into the previous colonial powers each state was subject to immediately prior to gaining independence.

\begin{tabular}{|c|c|c|c|c|c|}
\hline \multicolumn{6}{|c|}{ Right to life categories by former colonising power } \\
\hline $\begin{array}{l}\text { FORMER } \\
\text { COLONISER }\end{array}$ & \multirow[t]{2}{*}{ Belgium $^{a}$} & \multirow[t]{2}{*}{ Britain $^{b}$} & \multirow[t]{2}{*}{ France $^{C}$} & \multirow[t]{2}{*}{ Portugal $^{d}$} & \multirow[t]{2}{*}{ Other ${ }^{\mathrm{e}}$} \\
\hline $\begin{array}{l}\text { CATEGORIES } \\
\text { AND SUB- } \\
\text { CATEGORIES }\end{array}$ & & & & & \\
\hline \multicolumn{6}{|c|}{ No Internal Limitations } \\
\hline $\begin{array}{l}\text { Prohibition of } \\
\text { death penalty }\end{array}$ & 0 & $1^{t}$ & $1^{\mathrm{g}}$ & $5^{h}$ & $1^{1}$ \\
\hline $\begin{array}{l}\text { Only right to } \\
\text { life }\end{array}$ & $2^{5}$ & $2^{k}$ & $3^{t}$ & 0 & $1^{m}$ \\
\hline \multirow{2}{*}{$\begin{array}{l}\text { With other } \\
\text { rights }\end{array}$} & $1^{n}$ & $2^{0}$ & $9^{P}$ & 0 & 0 \\
\hline & 3 & 5 & 13 & 5 & 2 \\
\hline \multicolumn{6}{|c|}{ Internal Limitations } \\
\hline $\begin{array}{l}\text { Express } \\
\text { limitation }\end{array}$ & 0 & $13^{\mathrm{q}}$ & 0 & 0 & $2^{r}$ \\
\hline \multirow[t]{2}{*}{ Other } & 0 & 0 & $2^{5}$ & 0 & \\
\hline & & 13 & 2 & & 2 \\
\hline Inferentic & & & & & \\
\hline
\end{tabular}




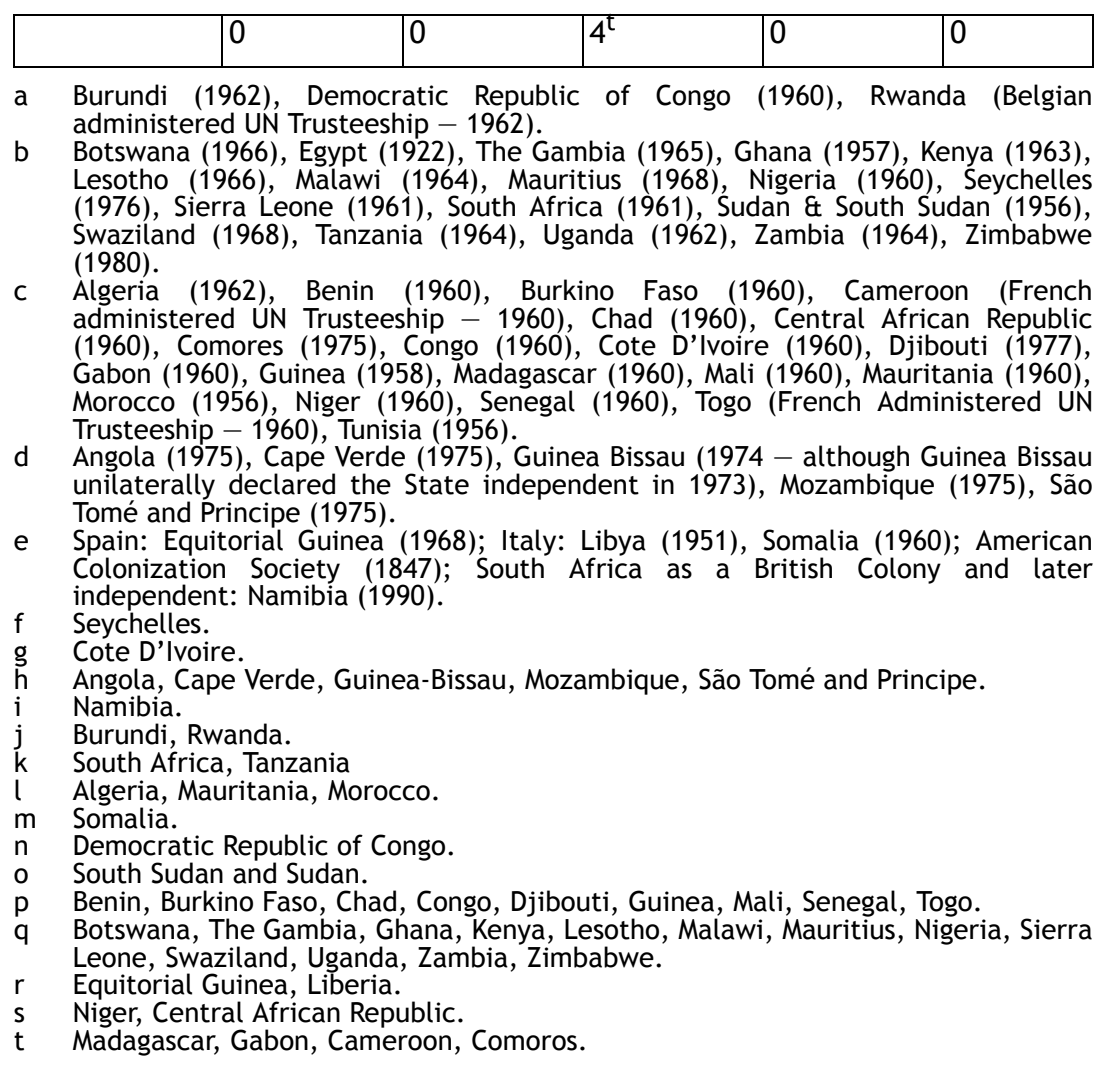

The above table highlights three interesting findings. Firstly, all the previous Portuguese colonies not only contain no limitation on the right to life in their respective constitutions but such constitutions expressly prohibit the death penalty in municipal systems. In contrast, a clear majority of constitutions providing for an express limitation (especially providing for the legality of the death penalty) belong to previous British colonies. Finally previous French colonies have a tendency either to group the right to life with other rights or only infer the right to life through the preamble of their constitutions. As a side note, it can be stated that the Belgian colonies contained no internal limitation on the right to life, but with only a data range of three countries it is hardly worthy of concern.

It comes as no surprise that the approach to formulating fundamental rights, such as the right to life, was strongly influenced by previous imperial powers. The first postcolonial constitutions of 
many African states were little more than 'dysfunctional duplications of their former imperial masters. 37 We will briefly investigate the reasons for the trends noted.

\subsection{Previous French colonies}

Most previous French colonies adopted the constitutional model of Charles De Gaulle - the so-called Fifth Republic Constitution - under the auspices of joining the Communaute francaise. ${ }^{38}$ The effect was that just under half of previous French Colonies or French Administered territories expressly referred to the French Declaration of the Rights of Man of 1789.39 Even the contemporary French Constitution still contains this reference. ${ }^{40}$ An equal number of colonies opted rather to refer directly to the Universal Declaration of 1948; some states referred to both. Other colonies, while not expressly referring to the 1789 or 1948 Declarations followed the same sequential form of the fourth and fifth republic constitutions by proclaiming or listing certain rights in the preamble, rather than the usual practice of enumerating these rights in separate chapters or title headings in the body of the constitution. ${ }^{41}$ Gabon, Comoros, Seychelles and Cameroon still follow this French constitutional tradition. ${ }^{42}$ The Independence Constitution of the Central African Republic also incorporated rights via the preamble alone, but subsequent constitutional amendments removed this feature.

\subsection{Previous British colonies}

The previous British colonies in Africa deviated from the British model insofar as introducing a Bill of Rights. The British system, relying heavily on common law, does not incorporate fundamental rights into the written constitutional document. ${ }^{43}$ This tradition continued in the

37 J Go 'Modelling the state: Post-colonial constitutions in Asia and Africa' (2002) 39

South East Asian Studies 559.

JM Mbauke 'What should Africans expect from their Constitutions?' (2013) 41 Denver Journal of International Law and Policy 161. Guinea was the only SubSaharan French Colony that rejected De Gaulle's offer.

39 Go (n 37 above) 574.

40 Preamble of the Constitution of the Republic of France 1958: "Le peuple français proclame solennellement son attachement aux Droits de l'Homme et aux principes de la souveraineté nationale tels qu'ils ont été définis par la Déclaration de 1789."

41 EM Fernando 'The American constitutional impact on the Philippine legal system' in LW Beer (ed) Constitutionalism in Asia: Asian Views of the American Influence (1979) 168.

42 See table $(C)$ below; note the Comores are not included in the table as it is not ranked on the Global Peace index.

43 DW Vick 'The Human Rights Act and the British Constitution' (2002) 37 Texas International Law Journal 337. 
legal systems of commonwealth countries such as Australia and New Zealand that sets out citizen's rights in separate statutes. ${ }^{44}$

The source of the constitutions thus has to be traced elsewhere. Nigeria, for example, out of a fear of insufficiently providing for minority groups, decided to deviate from the British model so as to provide certain constitutional guarantees. A committee established for minority rights in Nigeria recommended following a rights formulation as can be found in the European Convention for Human Rights. ${ }^{45}$ The Convention strongly influenced the Constitution and numerous critical similarities between the two documents can be noted. There seems to have been a strong diffusion effect: once Nigeria adopted the European Convention as a model, so too did many others. ${ }^{46}$ Article 2 of the Convention provides that '[e]veryone's right to life shall be protected by law. No one shall be deprived of his life intentionally save in the execution of a sentence of a court following his conviction of a crime for which this penalty is provided by law.' Article 2 continues to list private defence, use of force by law enforcement officials when absolutely necessary and the quelling of riots and insurrections as acts not deemed a violation of the right to life. The fingerprints of the European Convention can therefore clearly be observed in the former British colonies with similar express limitations on the right to life in their domestic constitutions.

\subsection{Previous Portuguese colonies}

Constitution of Cape Verde (1992) bears striking similarities on both substance and structure to the Constitution of Portugal. ${ }^{47}$

\subsection{Violence rates per identified category}

By assigning each State their ranking based on the Global Peace Index results of 2013 and determining the average per category, we will attempt to draw a corollary link between the protection of right which must be interpreted in terms of the levels of violence in a country - and the manner of articulation within the state's respective constitution.

To give credibility to this approach, a brief comment on the Global Peace Index (GPI) is necessary. The GPI is an index created by the Institute for Economics and Peace in consultation with independent experts, think-tanks and organisations. It uses 22 different indicators to roughly rank countries from least to most

New Zealand Statute, Australian Statute.

The European Convention for Human Rights, Rome, 4 November 1950.

Go (n 37 above) 579

M Bogdan 'The law of the Republic of Cape Verde after 25 years of independence' (2000) 44 Journal of African Law 88 86-95. 
violent and has been endorsed by Kofi Annan, Mary Robinson, Jimmy Carter, Archbishop Desmund Tutu and the Dalai Lama to name but a few. While the resultant ranking on the GPI cannot be described as 100 percent accurate, it is deemed to be the leading index of sorts and accurate especially with reference to identifying trends.

The first table (A) is an exposition of States whose constitutions contain no express internal limitation to the right to life:

The Right to Life Protected in the Absence of Internal Limitations

\begin{tabular}{|c|c|c|c|c|}
\hline Categories & Country & $\begin{array}{l}\text { Global Peace } \\
\text { Index rating }\end{array}$ & \begin{tabular}{|l|} 
Subtotals and \\
Totals
\end{tabular} & Average \\
\hline \multicolumn{5}{|c|}{ Specific prohibition of the death penalty } \\
\hline & Angola & 102 & & \\
\hline & Cote D'Ivoire & 151 & & \\
\hline & Guinea-Bissau & 132 & & \\
\hline & Mozambique & 61 & & \\
\hline & Namibia & 46 & & \\
\hline & & & 492 & 98.40 \\
\hline \multicolumn{5}{|c|}{ Only mentions right to life } \\
\hline & Algeria & 119 & & \\
\hline & Burundi & 144 & & \\
\hline & Guinea-Bissau & 132 & & \\
\hline & Mauritania & 122 & & \\
\hline & Morocco & 57 & & \\
\hline & Rwanda & 135 & & \\
\hline & Somalia & 161 & & \\
\hline & South Africa & 121 & & \\
\hline & Tanzania & 55 & & \\
\hline & & & 1046 & 116.22 \\
\hline \multicolumn{5}{|c|}{ Grouped with other rights } \\
\hline & Benin & 104 & & \\
\hline & Burkino Faso & 87 & & \\
\hline & Chad & 138 & & \\
\hline
\end{tabular}




\begin{tabular}{|l|l|l|l|l|}
\hline & Congo & 107 & & \\
\hline & $\begin{array}{l}\text { Democratic } \\
\text { Republic of } \\
\text { Congo }\end{array}$ & 156 & & \\
\hline & Djibouti & 63 & & \\
\hline & Guinea & 116 & & \\
\hline & Mali & 125 & & \\
\hline & Senegal & 85 & & \\
\hline & South Sudan & 143 & & \\
\hline & Sudan & 158 & & 112.42 \\
\hline & Togo & 67 & 1349 & 109.01 \\
\hline TOTAL & & & & \\
\hline & & & & \\
\hline & & & & \\
\hline
\end{tabular}

The following two tables set out the data for the two remaining categories: Constitutional formulations with internal limitations (B) and constitutions where the right to life has to be inferred (C):

The Right to Life subject to Internal Limitations

\begin{tabular}{|l|l|l|l|l|}
\hline Categories & Country & $\begin{array}{l}\text { Global Peace } \\
\text { Index rating }\end{array}$ & $\begin{array}{l}\text { Subtotals and } \\
\text { Totals }\end{array}$ & Average \\
\hline Death penalty & Botswana & 32 & & \\
\hline & $\begin{array}{l}|l| \\
\text { Gquitorial } \\
\text { Guinea }\end{array}$ & 89 & & \\
\hline & Eritrea & 120 & & \\
\hline & Ethiopia & 146 & & \\
\hline & Ghana & 58 & & \\
\hline & Kenya & 136 & & \\
\hline & Lesotho & 49 & & \\
\hline & Liberia & 80 & 74 & \\
\hline & Malawi & & & \\
\hline & & & & \\
\hline
\end{tabular}




\begin{tabular}{|l|l|l|l|l|}
\hline & Mauritius & 21 & & \\
\hline & Nigeria & 148 & & \\
\hline & Sierra Leone & 59 & & \\
\hline & Swaziland & 88 & & \\
\hline & The Gambia & 93 & & \\
\hline & Uganda & 106 & & \\
\hline & Zambia & 48 & & \\
\hline & Zimbabwe & 149 & & \\
\hline Other & & & 1496 & 88 \\
\hline & $\begin{array}{l}\text { Central } \\
\text { African } \\
\text { Republic }\end{array}$ & 153 & & \\
\hline & Niger & 146 & & \\
\hline Total & & & & 118.75 \\
\hline & & & & \\
\hline
\end{tabular}

The Right to Life by inference

\begin{tabular}{|l|l|}
\hline Country & Global Peace Index rating \\
\hline Madagascar & 90 \\
\hline Gabon & 76 \\
\hline Cameroon & 108 \\
\hline & \\
\hline Total & 274 \\
\hline Average & 91.33 \\
\hline
\end{tabular}

The data from Tables (A), (B) and (C) is summarised into Table (D) below. Table (D) serves as a summary of the average peace rating for each formulation of the right to life. The table does not include data on Cape Verde. The Comoros, São Tomé and Principe and the Seychelles as the Global Peace Index does not rate smaller island nations. 
Right to life provisions

The Right to Life Protected in the Absence of Internal Limitations

\begin{tabular}{|l|l|l|}
\hline & $\begin{array}{l}\text { Specific prohibition of } \\
\text { the death penalty }\end{array}$ & 98.4 \\
\hline & $\begin{array}{l}\text { Only mentions right to } \\
\text { life }\end{array}$ & 114.25 \\
\hline $\begin{array}{l}\text { Grouped with other } \\
\text { rights }\end{array}$ & 112.42 \\
\hline & 108.36 \\
\hline
\end{tabular}

The Right to Life subject to Internal Limitations

\begin{tabular}{|l|l|l|}
\hline & $\begin{array}{l}\text { Express limitation (e.g. } \\
\text { Death penalty) }\end{array}$ & 88 \\
\hline & Other & 149.5 \\
\hline & 118.75 \\
\hline The Right to Life by inference & \\
\hline & $\mathbf{9 1 . 3 3}$ \\
\hline
\end{tabular}

The data does not show any corollary link between clearer stipulation of the right to life or between unqualified versus qualified protection and violence. This amounts to a null hypothesis in which the unfortunate conclusion must be drawn that the wording -or upon extrapolation of this even the constitutional enshrinement- of the right to life is irrelevant in the on-the-ground reduction of violence. It is for this reason that we enter into a general discussion and look at specific instances of the perpetuation of violence.

\section{Violence in Africa and the right to life}

As already stated, the data analysed shows no link between clearer stipulation of the right to life or between unqualified versus qualified protection and violence in African Countries. The question then comes, what are the factors that continue to perpetuate violence in Africa?

Civil war, coups d'état, organised group violence for political, religious and economic ends, civil protest due to poor service delivery and robbery by gangs as well as individual murder and assault are some of the pre-dominant forms of violence in Africa. ${ }^{48}$ The right to 
life and its protection in Africa rests on more than just its legislative recognition and protection but on more complex social-economic and political factors. The legislative protection of the right to life in Africa, however, is important as it equips persons with a tool to hold their governments accountable for acts of violation of the right to life. ${ }^{49}$

\section{$5 \quad$ Recommendations}

It is our recommendation that the right to life be provided for in the body of all African Constitutions and entrenched so as to make it a non-derogable right. It should not be made subject to any limitations and mechanisms should be put in place to ensure that the right is justiciable. We suggest a model definition of the right to life as 'everyone has an inherent, non-derogable right to life.' 'Inherent' to stress that it's a an essential characteristic of being human, it need not be earned, that there are no classes of persons entitled thereto and those who aren't; 'non-derogable' in that, as in international law which recognizes the right to life as a peremptory norm that on a hierarchical scale, it must be placed higher than other rights and trump all other rights in competition therewith. ${ }^{50}$

49 It must however be noted that this is only effective if the right to life is justiciable.

50 C D'Amato 'It's a bird, it's a plane, it's jus cogens!' (2010) Faculty Working Papers. Paper 61 accessed online at http://scholarlycommons.law. northwestern.edu 10 September 2013. 